\title{
PENENTUAN DOSEN PEMBIMBING TERBAIK KULIAH KERJA NYATA MENGGUNAKAN METODE TOPSIS
}

\author{
Buhari $^{1}$, Hozairi ${ }^{2}$ \\ ${ }^{1,2}$ Program Studi Teknik Informatika, Universits Islam Madura, Pamekasan, Indonesia \\ buharinahrawi@gmail.com,dr.hozairi@gmail.com
}

\begin{abstract}
ABSTRAK
Kuliah Kerja Nyata (KKN) adalah kegiatan pengabdian kepada masyarakat yang dilakukan oleh mahasiswa dengan pendekatan lintas keilmuwan dengan tujuan menyelesaikan permasalahan yang ada dimasyarakat dengan menerapkan keilmuwan yang telah diperoleh semasa perkuliahan. Keberhasilan pelaksanaan KKN dilapangan sangat dipengaruhi oleh kinerja dosen pembimbing lapangan (DPL). Permasalahan yang dihadapi Lembaga Penelitian dan Pengabdian Kepada Masyarakat Universitas Islam Madura (LP2M-UIM) adalah menentukan DPL KKN terbaik, penentuan DPL KKN terbaik banyak mempertimbangkan beberapa kriteria sebagai dasar penilaian dan setiap kritera memiliki bobot nilai sehingga perlu metode untuk menyelesaikanya. TOPSIS adalah metode pengambilan keputusan yang mampu menyelesaiakn masalah multi criteria, prinsip kerja TOPSIS adalah alternatif yang dipilih harus memiliki jarak terdekat dari solusi ideal positif dan terjauh dari solusi ideal negatif. Penelitian ini telah merekomendasikan 3 (tiga) DPL KKN terbaik, yaitu: dosen A13 (0.741), dosen A4 (0.643), dan dosen A11 (0.637), dari lima belas DPL yang dinilai telah diperoleh tiga terbaik untuk ditetapkan menjadi DPL KKN terbaik di Universitas Islam Madura sehingga dosen tersebut layak untuk diberikan penghargaan
\end{abstract}

Keyword : $D P L, K K N, T O P S I S$

\section{PENDAHULUAN}

Universitas Islam Madura (UIM) adalah perguruan tinggi swasta yang berada di Pamekasan yang didirikan oleh beberapa kiai yang berafiliasi dengan Nadhlatul Ulama dan bertempat di Pondok Pesantren Miftahul Ulum Bettet. UIM memiliki banyak program studi mulai dari S1 dan D3 dan memiliki Mahasiswa \pm 3000 dan \pm 130 dosen. UIM menetapkan KKN sebagai matakuliah wajib yang harus diikuti oleh seluruh mahasiswa yang mencapai 110 SKS, KKN merupakan aktualisasi pelaksanaan Tri Dharma Perguruan Tinggi khususnya dalam pengabdian kepada masyarakat (Nyata, 2016).

KKN adalah bentuk kegiatan pengabdian kepada masyarakat oleh mahasiswa dengan pendekatan lintas keilmuan dan sektoral pada waktu dan daerah tertentu. KKN juga salah satu kegiatan wajib mahasiswa untuk memenuhi syarat kelulusan, kegiatan KKN merupakan momen bagi mahasiswa utuk mengaplikasikan ilmu yang di dapat ke dunia luar. Mahasiswa yang bisa melaksanakan KKN adalah mereka yang sudah menempuh > 96 SKS, artinya mereka sudah memiliki kemampuan keilmuwan yang cukup untuk terjun ke masyarakat, tapi untuk mengaplikasikan ke tempat KKN tidak akan maksimal tanpa adanya Dosen Pembimbing Lapangan (DPL) yang akan mengarahkan mahasiswa dari pembimbingan sampai pelaksanaan KKN (Nyata, 2016).

Dosen Pembimbing Lapangan (DPL) merupakan dosen yang bertugas untuk membimbing mahasiswa peserta KKN selama proses KKN berjalan \pm 30 hari, DPL berperan sebagai pembina, motivator, penasehat, pengawas, pengarah, penghubung, penyuluh, dan sekaligus penilai kegiatan mahasiswa di lapangan agar para mahasiswa KKN merubah perilaku dan kompetensinya sebagai bagian dari proses belajarnya.

Di Universitas Islam Madura DPL KKN setiap tahun selalu diberikan reward (penghargaan) namun proses pemilihanya selalu mendapatkan protes oleh DPL yang tidak terpilih, sehingga Lembaga Penelitian dan Pengabdian Kepada Masyarakat Universitas Islam Madura (LP2M UIM) harus lebih selektif dalam menilai masingmasing DPL. Oleh sebab itu Penentuan DPL KKN terbaik memiliki pengaruh besar terhadap kepercayaan publik kepada LP2M UIM, sehingga perlu sebuah sistem pendukung keputusan yang bisa membantu LP2M UIM menyelesaikan permasalahan tersebut, sehingga keputusan yang diambil berdasarkan hasil penilaian dari mahasiswa dan LP2M UIM dan bersifat terbuka bisa dilihat oleh siapa saja proses perhitunganya (Ahmad, 2018).

Penentuan DPL KKN terbaik merupakan permasalahan yang discret, tujuannya adalah untuk menetapkan DPL terbaik dari sejumlah DPL berdasarkan beberapa kriteria tertentu sehingga permasalahan tersebut dapat diselesaikan dengan metode Multi Criteria Decision Making (MCDM).

Metode MCDM yang dikembangkan untuk menentukan DPL KKN terbaik adalah Technique for Order of Preference by Similarity to Ideal Solution (TOPSIS), cara kerja metode tersebut adalah menggunakan prinsip alternatif yang terpilih harus memiliki jarak terdekat dari solusi ideal 
positif dan terjauh dari solusi ideal negatif dengan menggunakan jarak Euclidean.

Metode TOPSIS merupakan metode yang sering digunakan untuk mengambil keputusan, TOPSIS hampir sama dengan metode AHP dengan menggunakan kriteria sebagai indentifikator untuk menyelesaikan permasalahan multi kriteria. Metode TOPSIS memiliki banyak lebihan antara lain: (i) konsepnya sederhana dan mudah dipahami, (ii) komputasinya efisien, (iii) bisa dijadikan pengukur kriteria dan alternatif dan (iv)prosesnya lebih cepat (Maryana \& Mulyono, 2016), (Andryan, Effendi, Santoso, \& Hidayat, 2018).

\section{2. tinjauan pustaka}

\subsection{Sistem Pendukung Keputusan}

Sistem Pendukung Keputusan (SPK) adalah sebuah sistem yang menyediakan kemampuan untuk penyelesaian masalah dan komunikasi untuk permasalahan yang bersifat semi-terstruktur. SPK ditujukan untuk membantu pengambil keputusan memecahkan berbagai persoalan yang tidak terstruktur dengan memanfataakn data dan model yang tersimpan pada sistem komputer.

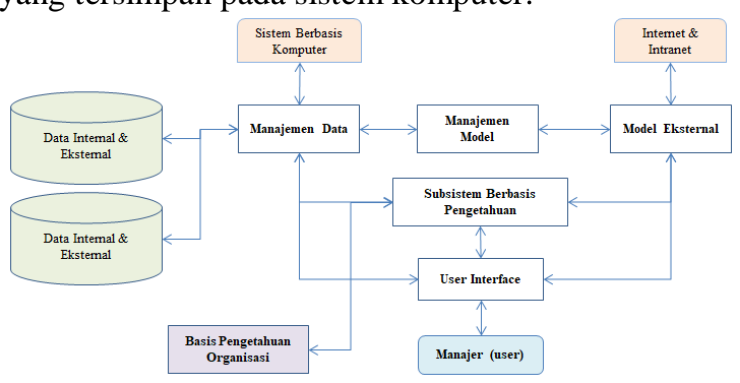

Gambar 1. Struktur Sistem Pendukung Keputusan

SPK memiliki beberapa karakteristik yang harus dipahami, yaitu:

1. Mendukung seluruh kegiatan organisasi.

2. Mampu berinteraksi antara keputusan yang satu dengan yang lainnya.

3. Mampu dimanfaatkan berulang kali dan bisa diupdate.

4. Memiliki komponen utama, yaitu data dan model.

5. Menggunakan data internal dan eksternal..

6. Memiliki kemampuan analisis data yang cepat.

7. Menggunakan beberapa model kuantitatif.

Ada beberapa tahapan dalam proses Proses pengambilan keputusan, yaitu:

1. Penelusuran (intelligence), proses ini merupakan tahap pendefinisian masalah dan identifikasi informasi yang dibutuhkan dengan persoalan yang dihadapi serta keputusan yang akan diambil.

2. Perancangan (design), proses ini merupakan tahap analisa dalam kaitan mencari atau merumuskan alternatif pemecahan masalah.
3. Pemilihan (choice), proses ini merupakan tahapan memilih alternatif solusi yang diperkirakan paling sesuai.

4. Implementasi (implementation), proses ini merupakan tahap pelaksanaan dari keputusan yang telah diambil.

SPK memiliki kelebihan dan kelemahan didalam penerapanya. Secara umum SPK memiliki kelebihan sebagai berikut (i) menunjang pembuatan keputusan manajemen untuk masalah semi terstruktur dan tidak terstruktur, (ii) membantu manajer menyelesaikan permasalahan yang komplek, (iii) membantu pembuatan keputusan secara kelompok maupun perorangan, (iv) menunjang pembuatan keputusan yang saling berurutan, (v) menunjang tahap-tahap pembuatan keputusan antara lain desain, choice, dan implementation (Hozairi, 2018).

Kelemhan SPK secara umum sebagai berikut: (i) tidak mampu memodelkan kemampuan bakat manusia, sehingga model yang ada didalam sistem tidak semuanya mencerminkan persoalan sebenarnya, (ii) kemampuan SPK terbatas pada pembendaharaan pengetahuan yang dimilikinya, (iii) proses yang dilakukan biasanya tergantung pada kemampuan perangkat lunak yang digunakannya (Heru Lumaksono, 2017).

\subsection{TOPSIS}

Technique for Order of Preference by Similarity to Ideal Solution (TOPSIS) adalah metode Multi-Attribute Decision Making (MADM) untuk menyelesaikan masalah yang komplek. TOPSIS bekerja didasarkan pada konsep dimana alternatif terpilih yang terbaik tidak hanya memiliki jarak terpendek dari solusi ideal positif, namun juga memiliki jarak terpanjang dari solusi ideal negatif. Solusi ideal positif didefinisikan sebagai jumlah dari seluruh nilai terbaik yang dapat dicapai untuk setiap atribut, sedangkan solusi negatif ideal terdiri dari seluruh nilai terburuk yang dicapai untuk setiap atribut (Chamid, 2016).

TOPSIS mempertimbangkan keduanya, jarak terhadap solusi ideal positif dan jarak terhadap solusi ideal negatif dengan mengambil kedekatan relatif terhadap solusi ideal positif. Berdasarkan perbandingan terhadap jarak relatifnya, susunan prioritas alternatif bisa dicapai. Metode ini banyak digunakan untuk menyelesaikan pengambilan keputusan disebabkan konsepnya sederhana, mudah dipahami, komputasinya efisien, dan memiliki kemampuan mengukur kinerja relatif dari alternatifalternatif keputusan (Purwokerto et al., 2015), (Muzakkir, 2017). TOPSIS banyak digunakan untuk membantu beberapa permasalahan didunia industri, pendidikan, pertanian, kelautan dan sosial (Maisari, Andreswari, \& Efendi, 2017). 


\section{METODE PENELITIAN}

Penelitian ini diawali dari penyebaran angket ke 100 responden yang mahasiswa peserta KKN, tujuan dari angket ini sebagai input data untuk menguji konsistensi terhadap penilaian masingmasing alternatif.

Tabel 1. Nama Kriteria

\begin{aligned} & \hline Kode Nama Kriteria \\ & \hline K1 Absensi \\ & K2 Partisipasi \\ & K3 Kreatifitas \\ & K4 Inovasi \\ & K5 Luaran \\ & K6 Dampak \\ & \hline\end{aligned}

Tabel 2. Nama Alternatif

\begin{aligned} & \hline Kode Nama Alternatif \\ & \hline A1 DPL-1 \\ & A2 DPL-2 \\ & A3 DPL-3 \\ & A4 DPL-4 \\ & A5 DPL-5 \\ & A6 DPL-6 \\ & A7 DPL-7 \\ & A8 DPL-8 \\ & A9 DPL-9 \\ & A10 DPL-10 \\ & A11 DPL-11 \\ & A12 DPL-12 \\ & A13 DPL-13 \\ & A14 DPL-14 \\ & A15 DPL-15 \\ & \hline\end{aligned}

Untuk menyelesaikan permasalahan multi kriteria dengan metode TOPSIS ada beberapa tahapan yang harus diselesaikan, yaitu:

- Membuat matriks keputusan yang ternormalisasi.

- Membuat matriks keputusan yang ternormalisasi terbobot.

- Menentukan matriks solusi idel positif dan matriks solusi ideal negatif.

- Menentukan jarak antara nilai setiap alternatif dengan matriks solusi ideal positif dan matriks solusi ideal negative.

- Menentukan nilai preferensi untuk setiap alternative.

- Perangkingan.
Berikut ini adalah matriks keputusan dengan 15 alternatif dan 6 kriteria.

$$
D=\left[\begin{array}{ccc}
x_{11} & \cdots & x_{1 n} \\
\vdots & \ddots & \vdots \\
x_{m 1} & \cdots & x_{m n}
\end{array}\right]
$$

Keterangan:

$\mathrm{D}=$ Matriks $\quad \mathrm{n}=$ Kriteria

$\mathrm{m}=$ Alternatif $\quad \mathrm{X}_{\mathrm{ij}}=$ Alternatif ke-i dan Kriteria ke-j

\subsection{Normalisasi Matrik Keputusan}

Setiap elemen pada matriks $D$ dinormalisasikan untuk mendapatkan matriks normalisasi $R$. Setiap normalisasi dari nilai $\mathrm{r}$ dapat dilakukan dengan perhitungan sebagai berikut:

Untuk $i=1,2,3, \ldots . ., m$;

$$
r_{i j}=\frac{x_{i j}}{\sqrt{\sum_{i=1}^{m} x_{i j}^{2}}}
$$

$$
j=1,2,3, \ldots ., n \text {. }
$$

\subsection{Pembobotan Matrik yang telah dinormalisasi}

Diberikan bobot $\mathrm{W}=(\mathrm{w} 1, \mathrm{w} 2, \ldots, \mathrm{wn})$, sehingga weighted normalized matrix $\mathrm{V}$ dapat dihasilkan sebagai berikut:

$$
V=\left[\begin{array}{ccc}
w_{11} r_{11} & \cdots & w_{1 n} r_{1 n} \\
\vdots & \ddots & \vdots \\
w_{m 1} r_{m 1} & \cdots & w_{n m} r_{n m}
\end{array}\right]
$$

Dengan: $i=1,2,3, \ldots . m$ dan $j=1,2,3, \ldots ., n$.

\subsection{Menentukan Solusi Ideal Positif dan Solusi Ideal Negatif}

Solusi ideal positif dinotasikan dengan $\mathrm{A}^{+}$dan solusi ideal negatif dinotasikan dengan $\mathrm{A}^{*}$. Menentukan solusi ideal (+) \& (-).

$$
\begin{aligned}
& A^{+}=\left\{\left(\max v_{i j} \mid j \in J\right)\left(\min v_{i j} \mid j \in J^{\prime}\right), i=1,2,3, \ldots m\right\}=\left\{v_{1}^{+}, v_{2}^{+}, \ldots v_{m}^{+}\right\} \\
& A^{-}=\left\{\left(\max v_{i j} \mid j \in J\right)\left(\min v_{i j} \mid j \in J^{\prime}\right), i=1,2,3, \ldots m\right\}=\left\{v_{1}^{-}, v_{2}^{-}, \ldots v_{m}^{-}\right\}
\end{aligned}
$$

Dimana:

$\mathrm{V}_{\mathrm{ij}}=$ elemen matriks $\mathrm{V}$ baris $k e-i$ dan kolom $k e-j$

$\mathrm{J}=\{\mathrm{j}=1,2,3, \ldots, \mathrm{n}$ dan $\mathrm{j}$ berhubung dengan benefit kriteria)

$\mathrm{J}^{\prime}=\{\mathrm{j}=1,2,3, \ldots, \mathrm{n}$ dan $\mathrm{j}$ berhubung dengan cost kriteria)

\subsection{Menghitung Separation Measure}

Separation measure ini merupakan pengukuran jarak dari suatu alternatif ke solusi ideal positif dan solusi ideal negatif. Perhitungan matematisnya adalah sebagai berikut:

- Separation measure untuk solusi ideal positif 


$$
S_{i}^{+}=\sqrt{\sum_{j=1}^{n}\left(v_{i j}-v_{j}^{+}\right)^{2}}, \text { dengan } i=1,2,3, \ldots, \mathrm{n}
$$

- Separation measure untuk solusi ideal negatif

$$
S_{i}^{-}=\sqrt{\sum_{j=1}^{n}\left(v_{i j}-v_{\bar{j}}^{-}\right)^{2}} \text {, dengan } i=1,2,3, \ldots, \mathrm{n}
$$

\subsection{Menghitung Kedekatan Relative dengan Ideal Positif}

Kedekatan relative dari alternatif $\mathrm{A}^{+}$dengan solusi ideal $\mathrm{A}^{-}$direpresentasikan dengan:

$$
C_{i}=\frac{S_{i}^{-}}{S_{i}^{-}+S_{i}^{+}} \text {, dengan } 0<C_{i}<1 \text { dan } i=1,2,3, \ldots, \mathrm{m}
$$

\subsection{Mengurutkan pilihan}

Alternatif dapat dirangking berdasarkan urutan $C_{i}$, maka dari itu, alternative terbaik adalah salah satu yang berjarak terpendek terhadap solusi ideal dan berjarak terjauh dengan solusi ideal negatif.

\section{HASIL PENELITIAN}

Hasil angket yang disebar kepada 100 responden dengan menilai 6 kriteria dan 15 alternatif, dengan rating penilaian sebagai berikut:

- 1 = Sangat Buruk

- $2=$ Buruk

- $3=$ Cukup

- $4=$ Baik

- $5=$ Sangat Baik

Tabel 3 merupakan proses pemberian bobot preferensi untuk setiap kriteria pada masing-masing alternatif dengan kriteria yang telah ditetapkan K1, K2, K3, K4, K5, K6 = [433443] artinya:

- $\mathrm{K} 1 \sim$ Absensi = Baik (4)

- $\mathrm{K} 2 \sim$ Partisipasi $=$ Cukup (3)

- $\mathrm{K} 3 \sim$ Kreatifitas $=$ Cukup $(3)$

- $\mathrm{K} 4 \sim$ Inovasi = Baik (4)

- $\mathrm{K} 5 \sim$ Luaran = Baik (4)

- K6 Dampak = Cukup (3)
Table 3. Nilai tabel keputusan

\begin{tabular}{ccccccc}
\hline & K1 & K2 & K3 & K4 & K5 & K6 \\
\hline A1 & 4 & 3 & 3 & 4 & 4 & 3 \\
A2 & 4 & 3 & 3 & 4 & 4 & 3 \\
A3 & 4 & 3 & 3 & 4 & 5 & 3 \\
A4 & 4 & 3 & 3 & 3 & 4 & 3 \\
A5 & 4 & 4 & 3 & 4 & 4 & 3 \\
A6 & 4 & 3 & 4 & 3 & 4 & 3 \\
A7 & 4 & 4 & 3 & 3 & 5 & 3 \\
A8 & 4 & 3 & 4 & 3 & 4 & 3 \\
A9 & 4 & 5 & 4 & 4 & 3 & 3 \\
A10 & 4 & 3 & 3 & 4 & 5 & 3 \\
A11 & 4 & 4 & 3 & 4 & 3 & 3 \\
A12 & 4 & 4 & 3 & 3 & 4 & 3 \\
A13 & 4 & 3 & 4 & 4 & 3 & 3 \\
A14 & 4 & 3 & 4 & 3 & 4 & 3 \\
A15 & 4 & 3 & 3 & 5 & 4 & 3 \\
\hline
\end{tabular}

Setelah didapatkan bobot preferensi setiap kriteria pada masing-masing alternatif, selanjutnya adalah mencari nilai kuadrat dan akar dari masingmasing kriteria seperti terlihat pada table 4 .

Berikut proses perhitungan nilai kuadrat dan akar pada kriteria daerah perbatasan [K1].

$$
\begin{aligned}
|\mathbf{K} 1|= & {[\mathrm{A} 1]^{2}+[\mathrm{A} 2]^{2}+[\mathrm{A} 3]^{2}+[\mathrm{A} 4]^{2}+[\mathrm{A} 5]^{2}+[\mathrm{A} 6]^{2} } \\
& +[\mathrm{A} 7]^{2}+[\mathrm{A} 8]^{2}+[\mathrm{A} 9]^{2}+[\mathrm{A} 10]^{2}+[\mathrm{A} 11]^{2}+ \\
& {[\mathrm{A} 12]^{2}+[\mathrm{A} 13]^{2}+[\mathrm{A} 14]^{2}+[\mathrm{A} 15]^{2} } \\
|\mathbf{K} 1|= & {[4 \mathrm{x} 4]+[4 \mathrm{x} 4]+[4 \mathrm{x} 4]+[4 \mathrm{x} 4]+[4 \mathrm{x} 4]+[4 \mathrm{x} 4] } \\
& +[4 \mathrm{x} 4]+[4 \mathrm{x} 4]+[4 \mathrm{x} 4]+[4 \mathrm{x} 4]+[4 \mathrm{x} 4]+ \\
& {[4 \mathrm{x} 4]+[4 \times 4]+[4 \mathrm{x} 4] } \\
|\mathbf{K} 1|= & \mathbf{2 4 0} \text { (nilai kuadrat) } \\
|\mathbf{K} \mathbf{1}|= & \sqrt{2} \mathbf{2 4 0 = 1 4 , 4 9 2 .}
\end{aligned}
$$

Tabel 4. Nilai kuadrat dan akar

\begin{tabular}{rrrrrrr}
\hline & \multicolumn{1}{c}{ K1 } & \multicolumn{1}{c}{ K2 } & \multicolumn{1}{c}{ K3 } & \multicolumn{1}{c}{ K4 } & \multicolumn{1}{c}{ K5 } & \multicolumn{1}{c}{ K6 } \\
\hline Nilai Kuadrat & 240 & 179 & 170 & 207 & 246 & 135 \\
Nilai Akar & 15,492 & 13,379 & 13,038 & 14,387 & 15,684 & 11,619 \\
\hline
\end{tabular}

Dengan cara yang sama akan diperoleh nilai akar dari beberapa kriteria diperoleh sebagai berikut:

$$
\begin{array}{ll}
\mathrm{K} 2=\sqrt{ } 179 & =11,136 \\
\mathrm{~K} 3=\sqrt{ } 170 & =13,928 \\
\mathrm{~K} 4=\sqrt{ } 207 & =10,583 \\
\mathrm{~K} 5=\sqrt{246} & =8,062 \\
\mathrm{~K} 6=\sqrt{ } 135 & =11,402
\end{array}
$$

Setelah diperoleh nilai kuadrat dan nilai akar pada masing-masing kriteria seperti table 4 , maka selanjutnya dilakukan proses perhitungan matrik normalisasi pada masing-masing alternatif seperti pada table 5 . 
Tabel 5. Nilai matrik normalisasi

\begin{tabular}{lllllll}
\hline & K1 & K2 & K3 & K4 & K5 & K6 \\
\hline A1 & 0,258 & 0,224 & 0,230 & 0,278 & 0,255 & 0,258 \\
A2 & 0,258 & 0,224 & 0,230 & 0,278 & 0,255 & 0,258 \\
$\mathbf{A 3}$ & 0,258 & 0,224 & 0,230 & 0,278 & 0,319 & 0,258 \\
$\mathbf{A 4}$ & 0,258 & 0,224 & 0,230 & 0,209 & 0,255 & 0,258 \\
A5 & 0,258 & 0,299 & 0,230 & 0,278 & 0,255 & 0,258 \\
A6 & 0,258 & 0,224 & 0,307 & 0,209 & 0,255 & 0,258 \\
A7 & 0,258 & 0,299 & 0,230 & 0,209 & 0,319 & 0,258 \\
A8 & 0,258 & 0,224 & 0,307 & 0,209 & 0,255 & 0,258 \\
A9 & 0,258 & 0,374 & 0,307 & 0,278 & 0,191 & 0,258 \\
A10 & 0,258 & 0,224 & 0,230 & 0,278 & 0,319 & 0,258 \\
$\mathbf{A 1 1}$ & 0,258 & 0,299 & 0,230 & 0,278 & 0,191 & 0,258 \\
$\mathbf{A 1 2}$ & 0,258 & 0,299 & 0,230 & 0,209 & 0,255 & 0,258 \\
$\mathbf{A 1 3}$ & 0,258 & 0,224 & 0,307 & 0,278 & 0,191 & 0,258 \\
$\mathbf{A 1 4}$ & 0,258 & 0,224 & 0,307 & 0,209 & 0,255 & 0,258 \\
$\mathbf{A 1 5}$ & 0,258 & 0,224 & 0,230 & 0,348 & 0,255 & 0,258 \\
\hline
\end{tabular}

Untuk perhitungan Absensi (K1):

$\mathrm{R}_{1-1}=\mathrm{X}_{1-1} / \mathrm{K}_{1}=4 / 15,492=0,258$
$\mathrm{R}_{2-1}=\mathrm{X}_{2-1} / \mathrm{K}_{1}=4 / 15,492=0,258$
$\mathrm{R}_{3-1}=\mathrm{X}_{3-1} / \mathrm{K}_{1}=4 / 15,492=0,258$
$\mathrm{R}_{4-1}=\mathrm{X}_{4-1} / \mathrm{K}_{1}=4 / 15,492=0,258$
$\mathrm{R}_{5-1}=\mathrm{X}_{5-1} / \mathrm{K}_{1}=4 / 15,492=0,258$
$\mathrm{R}_{6-1}=\mathrm{X}_{6-1} / \mathrm{K}_{1}=4 / 15,492=0,258$
$\mathrm{R}_{7-1}=\mathrm{X}_{7-1} / \mathrm{K}_{1}=4 / 15,492=0,258$
$\mathrm{R}_{8-1}=\mathrm{X}_{8-1} / \mathrm{K}_{1}=4 / 15,492=0,258$
$\mathrm{R}_{9-1}=\mathrm{X}_{9-1} / \mathrm{K}_{1}=4 / 15,492=0,258$
$\mathrm{R}_{10-1}=\mathrm{X}_{10-1} / \mathrm{K}_{1}=4 / 15,492=0,258$
$\mathrm{R}_{11-1}=\mathrm{X}_{11-1} / \mathrm{K}_{1}=4 / 15,492=0,258$
$\mathrm{R}_{12-1}=\mathrm{X}_{12-1} / \mathrm{K}_{1}=4 / 15,492=0,258$
$\mathrm{R}_{13-1}=\mathrm{X}_{13-1} / \mathrm{K}_{1}=4 / 15,492=0,258$
$\mathrm{R}_{14-1}=\mathrm{X}_{14-1} / \mathrm{K}_{1}=4 / 15,492=0,258$
$\mathrm{R}_{15-1}=\mathrm{X}_{15-1} / \mathrm{K}_{1}=4 / 15,492=0,258$

Dengan cara yang sama pada kriteria yang lain pada masing-masing alternatif dapat dilihat pada table 5. Setelah diperoleh nilai matrik ternormalisasi, langkah selanjutnya adalah menentukan matrik normalisasi terbobot.

Proses pemberian bobot pada masing-masing kriteria harus dinilai dari tingkat kepentingan, tiap kriteria dapat dinilai dari range 1 sampai 5, yaitu:

\begin{tabular}{cl}
\hline Range & Keterangan Bobot \\
\hline 1 & Tidak Penting \\
2 & Tidak Terlalu Penting \\
3 & Cukup Penting \\
4 & Penting \\
5 & Sangat Penting \\
\hline
\end{tabular}

Nilai bobot awal (W) digunakan untuk menunjukkan tingkat kepentingan relatif dari setiap kriteria. Bobot dari masing-masing kriteria tertera pada Tabel 6.
Tabel 6. Bobot kriteria

\begin{tabular}{cc}
\hline Kode & Bobot \\
\hline K1 & 4 \\
K2 & 5 \\
K3 & 3 \\
K4 & 3 \\
K5 & 5 \\
K6 & 3 \\
\hline
\end{tabular}

Setelah menentukan bobot dari masingmasing kriteria, maka berdasarkan langkah 1 dan persamaan 2, kita dapat menghitung matrik normalisasi terbobot yaitu:

$\mathrm{Y}_{1-1}=\mathrm{W}_{11} / \mathrm{R}_{1-1}=4 / 0,258=15,492$
$\mathrm{Y}_{2-1}=\mathrm{W}_{11} / \mathrm{R}_{2-1}=4 / 0,258=15,492$
$\mathrm{Y}_{3-1}=\mathrm{W}_{11} / \mathrm{R}_{3-1}=4 / 0,258=15,492$
$\mathrm{Y}_{4-1}=\mathrm{W}_{11} / \mathrm{R}_{4-1}=4 / 0,258=15,492$
$\mathrm{Y}_{5-1}=\mathrm{W}_{11} / \mathrm{R}_{5-1}=4 / 0,258=15,492$
$\mathrm{Y}_{6-1}=\mathrm{W}_{11} / \mathrm{R}_{6-1}=4 / 0,258=15,492$
$\mathrm{Y}_{7-1}=\mathrm{W}_{11} / \mathrm{R}_{7-1}=4 / 0,258=15,492$
$\mathrm{Y}_{8-1}=\mathrm{W}_{11} / \mathrm{R}_{8-1}=4 / 0,258=15,492$
$\mathrm{Y}_{9-1}=\mathrm{W}_{11} / \mathrm{R}_{9-1}=4 / 0,258=15,492$
$\mathrm{Y}_{10-1}=\mathrm{W}_{11} / \mathrm{R}_{10-1}=4 / 0,258=15,492$
$\mathrm{Y}_{11-1}=\mathrm{W}_{11} / \mathrm{R}_{11-1}=4 / 0,258=15,492$
$\mathrm{Y}_{12-1}=\mathrm{W}_{11} / \mathrm{R}_{12-1}=4 / 0,258=15,492$
$\mathrm{Y}_{13-1}=\mathrm{W}_{11} / \mathrm{R}_{13-1}=4 / 0,258=15,492$
$\mathrm{Y}_{14-1}=\mathrm{W}_{11} / \mathrm{R}_{14-1}=4 / 0,258=15,492$
$\mathrm{Y}_{15-1}=\mathrm{W}_{11} / \mathrm{R}_{15-1}=4 / 0,258=15,492$

Tabel 7. Nilai matrik normalisasi terbobot

\begin{tabular}{ccccccc}
\hline & K1 & K2 & K3 & K4 & K5 & K6 \\
\hline $\mathbf{A 1}$ & 15,492 & 22,298 & 13,038 & 10,791 & 19,605 & 11,619 \\
$\mathbf{A 2}$ & 15,492 & 22,298 & 13,038 & 10,791 & 19,605 & 11,619 \\
$\mathbf{A 3}$ & 15,492 & 22,298 & 13,038 & 10,791 & 15,684 & 11,619 \\
$\mathbf{A 4}$ & 15,492 & 22,298 & 13,038 & 14,387 & 19,605 & 11,619 \\
$\mathbf{A 5}$ & 15,492 & 16,724 & 13,038 & 10,791 & 19,605 & 11,619 \\
$\mathbf{A 6}$ & 15,492 & 22,298 & 9,779 & 14,387 & 19,605 & 11,619 \\
$\mathbf{A 7}$ & 15,492 & 16,724 & 13,038 & 14,387 & 15,684 & 11,619 \\
$\mathbf{A 8}$ & 15,492 & 22,298 & 9,779 & 14,387 & 19,605 & 11,619 \\
$\mathbf{A 9}$ & 15,492 & 13,379 & 9,779 & 10,791 & 26,141 & 11,619 \\
$\mathbf{A 1 0}$ & 15,492 & 22,298 & 13,038 & 10,791 & 15,684 & 11,619 \\
$\mathbf{A 1 1}$ & 15,492 & 16,724 & 13,038 & 10,791 & 26,141 & 11,619 \\
$\mathbf{A 1 2}$ & 15,492 & 16,724 & 13,038 & 14,387 & 19,605 & 11,619 \\
$\mathbf{A 1 3}$ & 15,492 & 22,298 & 9,779 & 10,791 & 26,141 & 11,619 \\
$\mathbf{A 1 4}$ & 15,492 & 22,298 & 9,779 & 14,387 & 19,605 & 11,619 \\
$\mathbf{A 1 5}$ & 15,492 & 22,298 & 13,038 & 8,632 & 19,605 & 11,619 \\
\hline & & & & & &
\end{tabular}

Langkah selanjutnya yaitu menentukan matrik solusi ideal positif dan matrik solusi ideal negatif berdasarkan persamaan 3 dan 4 .

Matrik solusi ideal positif $\left(\mathrm{Yij}^{+}\right)$:

$$
\begin{aligned}
& A^{+}=\left(y_{1}^{+}, y_{2}^{+}, y_{3}^{+}, \ldots ., y_{n}^{+}\right) ; \\
& A^{-}=\left(y_{1}^{-}, y_{2}^{-}, y_{3}^{-}, \ldots ., y_{n}^{-}\right) ; \\
& Y_{J}^{+}=\left\{\begin{array}{l}
\max _{i} y_{i j} ; \\
\min _{i} y_{i j} ;
\end{array}\right.
\end{aligned}
$$


Solusi ideal positif dihitung sebagai berikut:

$Y_{1}^{+}=\max (15.492+15.492+\cdots)=15.492$

$Y_{2}^{+}=\max (22.298+22.298+\cdots)=22.298$

Dan seterusnya.

$\mathbf{A}^{+}=(15.492,22.298,13.038,14.387,26.141$, 11.619)

Solusi ideal negatif dihitung sebagai berikut :

$Y_{1}^{+}=\min (15.492+15.492+\cdots)=15.492$

$Y_{2}^{+}=\min (22.298+22.298+\cdots)=13.379$

Dan seterusnya.

$\mathbf{A}^{-}=(15.492,13.379,9.779,8.632,15.648,11.619)$

Demikian seterusnya, terakhir diperoleh solusi ideal positif dan solusi ideal negatif:

Tabel 8. Matrik solusi ideal positif dan negatif

\begin{tabular}{rllrrrl}
\hline & K1 & K2 & \multicolumn{1}{c}{ K3 } & \multicolumn{1}{c}{ K4 } & \multicolumn{1}{c}{ K5 } & \multicolumn{1}{c}{ K6 } \\
\hline Solusi Ideal (+) & 15,492 & 22,298 & 13,038 & 14,387 & 26,141 & 11,619 \\
Solusi Ideal (-) & 15,492 & 13,379 & 9,779 & 8,632 & 15,684 & 11,619 \\
\hline
\end{tabular}

Tahapan berikutnya adalah menentukan jarak antara nilai setiap alternatif dengan matriks solusi ideal positif \& matriks solusi ideal negatif. Untuk mencari jarak antar alternatif dengan matriks solusi ideal positif dapat menggunakan persamaan sebagai berikut:

$D_{i}^{+}=\sqrt{\sum_{j=1}^{n}\left(y_{i}^{+}-y_{i j}\right)^{2}}$;

Jarak antara alternatif A, dengan solusi ideal negatif dirumuskan sebagai:

$D_{i}^{-}=\sqrt{\sum_{j=1}^{n}\left(y_{i j}-y_{i}^{-}\right)^{2}} ; \quad \mathrm{i}=1,2, \ldots ., \mathrm{m}$

Membuat jarak antar nilai terbobot setiap alternatif terhadap solusi ideal positif. Nilai jarak solusi ideal positif pada masing-masing alternatif.

Tabel 9. Nilai kuadrat solusi ideal positif dan negatif

\begin{tabular}{crr}
\hline Kuadrat & \multicolumn{1}{c}{ Plus (+) } & \multicolumn{1}{c}{ Min (-) } \\
\hline A1 & 55,646 & 110,213 \\
A2 & 55,646 & 110,213 \\
A3 & 122,271 & 94,838 \\
A4 & 42,708 & 138,676 \\
A5 & 86,722 & 41,845 \\
A6 & 53,333 & 128,051 \\
A7 & 140,410 & 54,933 \\
A8 & 53,333 & 128,051 \\
A9 & 103,118 & 113,991 \\
A10 & 122,271 & 94,838 \\
A11 & 44,014 & 135,803 \\
A12 & 73,785 & 70,308 \\
A13 & 23,563 & 193,546 \\
A14 & 53,333 & 128,051 \\
A15 & 75,828 & 105,556 \\
\hline
\end{tabular}

Demikian seterusnya, terakhir diperoleh jarak solusi ideal positif dan solusi ideal negatif.

Tabel 10. Nilai Max dan Min nilai alternatif

\begin{tabular}{crr}
\hline Alternatif & \multicolumn{1}{c}{ Max } & \multicolumn{1}{c}{ Min } \\
\hline A1 & 7,460 & 10,498 \\
A2 & 7,460 & 10,498 \\
A3 & 11,058 & 9,738 \\
A4 & 6,535 & 11,776 \\
A5 & 9,312 & 6,469 \\
A6 & 7,303 & 11,316 \\
A7 & 11,849 & 7,412 \\
A8 & 7,303 & 11,316 \\
A9 & 10,155 & 10,677 \\
A10 & 11,058 & 9,738 \\
A11 & 6,634 & 11,653 \\
A12 & 8,590 & 8,385 \\
A13 & 4,854 & 13,912 \\
A14 & 7,303 & 11,316 \\
A15 & 8,708 & 10,274 \\
\hline
\end{tabular}

Langkah terakhir dalam perhitungan TOPSIS adalah mencari nilai preferensi untuk setiap alternatif diberikan sesuai dengan persamaan berikut ini.

$V_{i}=\frac{D_{i}^{-}}{D_{i}^{-}+D_{i}^{+}} ; \quad \mathrm{i}=1,2, \ldots ., \mathrm{m}$

Nilai Vi yang lebih besar menunjukan bahwa alternatif Ai lebih dipilih.

Menghitung nilai preferensi:

a. Nilai preferensi DPL KKN (A1)

$$
V_{1}=\frac{D_{1}^{-}}{D_{1}^{-}+D_{1}^{+}}=\frac{10.498}{7.460+10.498}=0.585
$$

b. Nilai preferensi DPL KKN (A2)

$$
V_{2}=\frac{D_{2}^{-}}{D_{2}^{-}+D_{2}^{+}}=\frac{10.498}{7.460+10.498}=0.585
$$

c. Nilai preferensi DPL KKN (A3)

$$
V_{3}=\frac{D_{3}^{-}}{D_{3}^{-}+D_{3}^{+}}=\frac{9.738}{11.058+9.738}=0.468
$$

d. Nilai preferensi DPL KKN (A4)

$$
V_{4}=\frac{D_{4}^{-}}{D_{4}^{-}+D_{4}^{+}}=\frac{11.776}{6.535+11.776}=0.643
$$

e. Nilai preferensi DPL KKN (A5)

$$
V_{5}=\frac{D_{5}^{-}}{D_{5}^{-}+D_{5}^{+}}=\frac{6.469}{9.312+6.469}=0.410
$$

f. Nilai preferensi DPL KKN (A6)

$$
V_{6}=\frac{D_{6}^{-}}{D_{6}^{-}+D_{6}^{+}}=\frac{11.316}{7.303+11.316}=0.643
$$

g. Nilai preferensi DPL KKN (A7)

$$
V_{7}=\frac{D_{7}^{-}}{D_{7}^{-}+D_{7}^{+}}=\frac{7.412}{11.849+7.412}=0.410
$$


h. Nilai preferensi DPL KKN (A8)

$$
V_{8}=\frac{D_{8}^{-}}{D_{8}^{-}+D_{8}^{+}}=\frac{11.316}{7.303+11.316}=0.608
$$

i. Nilai preferensi DPL KKN (A9)

$$
V_{9}=\frac{D_{9}^{-}}{D_{9}^{-}+D_{9}^{+}}=\frac{10.677}{10.155+10.677}=0.385
$$

j. Nilai preferensi DPL KKN (A10)

$$
V_{10}=\frac{D_{10}^{-}}{D_{10}^{-}+D_{10}^{+}}=\frac{9.738}{11.058+9.738}=0.585
$$

k. Nilai preferensi DPL KKN (A11)

$$
V_{11}=\frac{D_{11}^{-}}{D_{11}^{-}+D_{11}^{+}}=\frac{11.653}{6.634+11.653}=0.637
$$

1. Nilai preferensi DPL KKN (A12)

$$
V_{12}=\frac{D_{12}^{-}}{D_{12}^{-}+D_{12}^{+}}=\frac{8.385}{8.590+8.385}=0.494
$$

m. Nilai preferensi DPL KKN (A13)

$$
V_{13}=\frac{D_{13}^{-}}{D_{13}^{-}+D_{13}^{+}}=\frac{13.912}{4.854+13.912}=0.741
$$

n. Nilai preferensi DPL KKN (A14)

$$
V_{14}=\frac{D_{14}^{-}}{D_{14}^{-}+D_{14}^{+}}=\frac{11.316}{7.303+11.316}=0.608
$$

o. Nilai preferensi DPL KKN (A15)

$$
V_{15}=\frac{D_{15}^{-}}{D_{15}^{-}+D_{15}^{+}}=\frac{10.274}{8.708+10.274}=0.541
$$

Tabel 11. Nilai preferensi setiap alternatif

\begin{tabular}{|r|r|}
\hline $\mathbf{A 1}$ & 0,585 \\
\hline $\mathbf{A 2}$ & 0,585 \\
\hline $\mathbf{A 3}$ & 0,468 \\
\hline $\mathbf{A 4}$ & 0,643 \\
\hline $\mathbf{A 5}$ & 0,410 \\
\hline $\mathbf{A 6}$ & 0,608 \\
\hline $\mathbf{A 7}$ & 0,385 \\
\hline $\mathbf{A 8}$ & 0,608 \\
\hline $\mathbf{A 9}$ & 0,513 \\
\hline $\mathbf{A 1 0}$ & 0,468 \\
\hline $\mathbf{A 1 1}$ & 0,637 \\
\hline $\mathbf{A 1 2}$ & 0,494 \\
\hline $\mathbf{A 1 3}$ & 0,741 \\
\hline $\mathbf{A 1 4}$ & 0,608 \\
\hline $\mathbf{A 1 5}$ & 0,541 \\
\hline
\end{tabular}

Berdasarkan nilai preferensi terbesar A13 $=0.741$, A4 $=0.643$ dan A11 $=0.637$, maka pemilihan DPL KKN Terbaik diberikan kepada DPL A13, A4 dan A11.

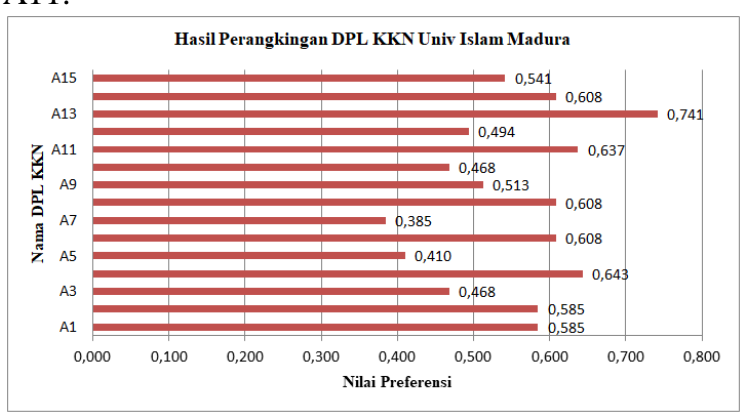

Gambar 2. Hasil Perangkingan TOPSIS
Berdasarkan Gambar 2 hasil perangkingan Dosen Pembimbing Lapangan Kuliah Kerja Nyata terlihat bahwa rata-rata DPL KKN memiliki kinerja yang baik dan bagus dengan capaian nilai diatas rata-rata, hal tersebut dipengaruhi oleh faktor proses seleksi DPL, proses pembekalan DPL dan keahlian masing-masing DPL.

\section{KESIMPULAN}

Berdasarkan hasil penelitian yang telah dilakukan dapat diambil kesimpulan sebagai berikut:

- Kriteria dasar yang bisa dijadikan pertimbangan untuk menentukan DPL KKN terbaik adalah: absensi kehadiran DPL, partisipasi DPL terhadap kegiatan KKN, kreatifitas DPL, inovasi DPL, luaran program $\mathrm{KKN}$ dan dampak program KKN.

- Hasil perhitungan TOPSIS untuk pemilihan DPL KKN terbaik adalah A13 $=0.741$, A4=0.643 dan A11=637.

- Hasil Perhitungan TOPSIS ini akan dijadikan pertimbangan untuk menentukan DPL KKN terbaik untuk diberikan reward oleh Universitas Islam Madura.

\section{DAFTAR PUSTAKA}

Ahmad, D. (2018). Pedoman Akademik Universitas Islam Madura Tahun Akademik 2018-2019.

Andryan, K., Effendi, S., Santoso, E., \& Hidayat, N. (2018). Implementasi Metode TOPSIS Untuk Penentuan Finalis Duta Wisata Joko Roro Kabupaten Malang ( Studi Kasus : Paguyuban Joko Roro ). Pengembangan Teknologi Informasi Dan Ilmu Komputer, 2(2).

Chamid, A. A. (2016). Penerapan Metode TOPSIS Untuk Menentukan Prioritas Kondisi Rumah. SIMETRIS, 7(2), 537-544.

Heru Lumaksono, H. (2017). Sistem Pendukung Keputusan untuk Menentukan Alat Tangkap yang Sesuai bagi Nelayan di Madura. In Seminar MASTER 2017 PPNS (Vol. 1509, pp. 1-6).

Hozairi, Y. K. (2018). Decision Support System Determination of Main Work Unit in WPP-711 using Fuzzy TOPSIS. Knowledge Engineering and Data Science, 1(1), 8-19.

Maisari, K. D., Andreswari, D., \& Efendi, R. (2017). Implementasi Metode TOPSIS dengan Pembobotan ENTROPY Untuk Penentuan Calon Penerima Bantuan Siswa Miskin (BSM) APBD Kota Bengkulu. Rekursif, 5(2).

Maryana, S., \& Mulyono, A. (2016). Penerapan Metode Topsis Pada Kualifikasi Peserta Sertifikasi Guru. KOMPUTASI, 13(2), 61-70.

Muzakkir, I. (2017). Penerapan metode topsis untuk sistem pendukung keputusan penentuan keluarga miskin pada desa panca karsa II. ILKOM, 9, 274-281. 
Nyata, K. (2016). Buku Panduan Kuliah Kerja Nyata (KKN) - Universitas Islam Madura. 5.

Purwokerto, M., Kurniawan, E., Mustafidah, H., Shofiyani, A., Raya, J., \& Waluh, D. (2015). Metode TOPSIS untuk Menentukan Penerimaan Mahasiswa Baru Pendidikan Dokter di Universitas Muhammadiyah Purwokerto ( TOPSIS Method to Determine New Students Admission at Medical School in University of. JUITA, III(November), 201206. 